\title{
KAJIAN EFEKTIVITAS EKSTRAK GEL IKAN TOMAN (Channa micropeltes) PADA LUKA BAKAR MENCIT (Mus musculus)
}

\author{
Firlianty, Hermansyah, Windarina Samosir \\ Program Studi Teknologi Hasil Perikanan, Jurusan Perikanan, FAPERTA Universitas Palangka Raya \\ Alamat : Jl. Yos Sudarso Kampus UPR Palangka Raya 73112 \\ corresponding author: firlianty80@gmail.com
}

(Dikirim 17-12-2019; Diterima 31-12-2019)

\begin{abstract}
This study aims to know the effectivity of snakehead (Channa micropeltes) gel extract on the burns healing of rat (Mus musculus). It was carried out for 4 months, September 2018 to January 2019. The study employed an experimental method of Complete Randomized Design with 4 treatmnets and 3 replications. Treatment $A$ was control, B used $1.5 \%$ gel extract of $C$. micropeltes, $C$ used $3 \%$, and D used $4.5 \%$, respectively. Results revealed that in day-4, 8 and 12 the administration of gel extract of $C$. micropeltes gave significant effect on the burns healing of rat (Mus musculus) (Fcalc.> Ftab., 0.05).

Keywords : gel extract, Channa micropeltes, rat Mus musculus, burns healing.
\end{abstract}

\begin{abstract}
ABSTRAK
Penelitian ini bertujuan untuk mengetahui kajian efektivitas ekstrak gel ikan toman (Channa micropeltes) pada penyembuhan luka bakar mencit (Mus musculus). Penelitian ini dilkukan selama 4 bulan, dimulai dari bulan September 2018 sampai Januari 2019. Penelitian ini menggunakan metode eksperimen dan analisis data menggunakan rancangan acak lengkap dengan 4 perlakun dan tiga ulangan: perlakuan $\mathrm{A}$ sebagai control, perlakuan B pemberian gel ekstrak ikan toman (Channa micropeltes) $1.5 \%$, perlakuan C $3 \%$ dan perlakuan D $4.5 \%$. hasil penelitian menunjukkan bahwa pada hari ke 4, hari ke 8 dan hari ke 12 menunjukkan bahwa pemberian ekstrak gel berpengaruh nyata terhadap perubahan panjang luka bakar mencit (Mus musculus) $(P>0.05)$ dan pemberian ekstrak gel ikan toman (Channa micropeletes) memberikan pengaruh yang nyata terhadap persentase penyembuhan luka bakar mencit (Mus musculus) $(P>0.05)$. hasil uji invivo pada mencit jantan dengan pemberian ekstrak gelnikan toman dapat mempercept penyembuhan luka bakar pada mencit.
\end{abstract}

Kata kunci : Ekstrak Gel Ikan Toman (Channa micropeltes) sebagai penyembuh luka bakar. 


\section{PENDAHULUAN}

Penggunaan hewan atau bagian-bagian hewan sebagai salah satu bahan alternatif dalam terapi pengobatan belum mengalami perkembangan yang berarti, padahal jika ditinjau dari segi sumber daya alam khususnya perairan Indonesia sangat potensial untuk dikembangkan menjadi sumber bahan dalam terapi pengobatan. Secara empiris sebagian masyarakat Indonesia percaya dengan mengkonsumsi daging ikan toman (Channa micropeltes) dapat membantu mempercepat penyembuhan luka. Pemanfaatan hewan-hewan laut maupun hewan- hewan sungai sebagai bahan pengobatan saat ini masih dalam tahap pengembangan, contohnya penggunaan ikan sebagai bahan dalam terapi pengobatan.

Di Indonesia, luka bakar masih merupakan problem yang berat. Perawatan dan rehabilitasinya masih sukar dan memerlukan ketekunan, biaya yang mahal, tenaga yang terlatih dan terampil. Sediaan gel mempunyai beberapa keuntungan diantaranya tidak lengket, mudah mengering, dan membentuk lapisan film yang tipis sehingga mudah dicuci, beberapa zat khasiat yang sering digunakan adalah seperti silver (perak) sulfadiazine, metronidazole, providon iodide, antiinflamasi dan analgetika. Asam lemak, asam amino, kolagen dan amylose juga dapat diberikan untuk memberikan nutrisi pada kulit yang terbakar (Mulyani et al., 2016)

Protein telah diketahui dapat mempercepat penyembuhan luka melalui pemberial oral, parental dan lokal. Salah satu kandungan dari ikan toman yakni protein albumin. Albumin merupakan protein globular yang sering diaplikasikan secara klinis untuk perbaikan gizi dan penyembuhan luka paska operasi. Menurut (Firlianty et al., 2013) pada salah satu jenis ikan family Channidae memiliki kadar protein 19,69\% dan albumin sebanyak 5,35 \%. Albumin berfungsi mengatur tekanan osmotik di dalam darah, menjaga keberadaan air dalam plasma darah sehingga dapat mempertahankan volume darah dalam tubuh, sebagai sarana pengangkut atau transportasi. Albumin juga bermanfaat dalam pembentukan jaringan tubuh yang baru pada saat usia pertumbuhan dan mempercepat penyembuhan jaringan tubuh, misalnya sesudah operasi, luka bakar dan saat sakit (Hairima et al., 2014 dalam Putri et al., 2016).

\section{METODE PENELITIAN}

\section{Alat dan Bahan}

Alat-alat yang dibutuhkan dalam pembuatan gel

Gelas kimia (pyrex), Gelas ukur, cawan petri, gelas objek kaca, pipet volume, pipet tetes, pipet skala, corong kaca, batang pengaduk, magnetic stirrer, $\mathrm{pH}$ meter digital, sentrifuge, timbangan analitik, Thermometer, Aluminium foil, Scalpel blade 11, Pisau, Nampan, Talenan, Kompor gas, Kain blacu, Alat pres modifikasi, Mangkok stainless, Kapas, Penggaris.

Bahan yang dibutuhkan dalam proses pembuatan gel: Ikan toman (Channa micropelyes), HPMC 2910, Trietanolamin, Propil Paraben, Propil Glikol, Akohol, Aquadest.

Alat-alat yang digunakan dalam percobaan ini sebagai berikut:

Tempat tikus, Penggaris, Alat pencukur, Timbangan, Sarung tangan, Spidol, Kertas Koran, injeksi, Gunting, Pinset, Kamera, Logam pembakar.

Hewan percobaan pada penelitian ini yakni menggunakan mencit (Mus musculus) jantan yang di peroleh dari peternak mencit di Pangkoh 1 Kabupaten Pulang Pisau Provinsi Kalimantan tengah, dengan kriteria sebagai berikut: Kondisi sehat dan normal, berumur 3 bulan.

\section{Prosedur Pembuatan Gel Ekstrak Ikan Toman (Channa micropeltes)}

Pembuatan Gel ikan toman terdiri dari empat fase yaitu:

Fase I yakni menentukan HPMC sesuai dengan konsentrasi kemudian dikembangkan dengan akuades dalam gelas kimia $50 \mathrm{ml}$, Fase ke II mencampurkan Trietanolamin (TEA) pada HPMC yang didispresikan secara bersamaan ditambahkan ekstrak ikan toman dan diaduk hingga homogen, Fase III Metil paraben, propil paraben dilarutkan kedalam Propelin Glikol dengan menggunakan gelas kimia 50 $\mathrm{ml}$, Fase IV yakni melakukan pencampuran fase I, II dan III pada gelas kimia $100 \mathrm{ml}$ sambil diaduk terus menerus hingga homogen.

\section{Prosedur Dalam Percobaan Kepada Tikus Adalah Sebagai Berikut:}

Menyiapkan wadah mencit dalam masingmasing perlakuan, masukkan mencit dengan bobot yang seragam pada masig-masing tempat yang telah di siapkan, timbang berat masing-masing sapel 
mencit adaptasi mencit dengan lingkungan baru, serta beri perlakuan yang sama pada semua sampel mencit selama 10 hari, tentukan daerah yang akan dibuat luka bakar, hilangkan bulu dengan mencukur sesuai dengan luas area luka bakar yang diinginkan, pasang perlak yang dan alasnya dibawah mencit yang akan dibuat luka bakar, cuci tangan dan pakai sarung tangan, sebelum mencit di lukai dilakukan anestesi dengan dosis lidokain yang digunakan dalam penelitian ini sebesar 0,2 cc, ditempel koin diameter 2 $\mathrm{cm}$ selama 5 detik yang telah dipanaskan selama 1 menit, dilakukan sampai mencapai bagian atas dermis sehingga terjadi pelepuhan (Hasyim et al., 2012). Kemudian beri perlakuan yang berbeda pada setiap sampel Mencit. Untuk perlakuan A sebagai kontrol, perlakuan $B$ diberi gel dengan dosis ekstrak ikan toman $1.5 \%$, perlakuan $\mathrm{C}$ diberi dosis ekstrak ikan toman $3.0 \%$ dan untuk perlakuan $D$ diberi dosis ekstrak ikan toman $4.5 \%$, amati perkembangan luka pada masing-masing sampel mencit yang telah diberi perlakuan yang berbeda selama 12 hari.

\section{HASIL DAN PEMBAHASAN}

\section{Pengukuran $\mathrm{pH}$}

Pada perlakuan $\mathrm{A}(0 \%) \mathrm{pH}$ yang diperoleh ratarata 8.5 , pada pada perlakuan $\mathrm{B}(1.50 \%)$ di peroleh rata-rata $\mathrm{pH} 8.46$, pada perlakuan $\mathrm{C}(3 \%)$ rata-rata $\mathrm{pH}$ yang diperoleh 8.5 dan pada perlakuan $\mathrm{D}(4.5) \mathrm{pH}$ yang di peroleh 8.4. dimana $\mathrm{pH}$ yang paling tinggi terdapat pada perlakuan $\mathrm{A}$ dan perlakuan $\mathrm{C}$.

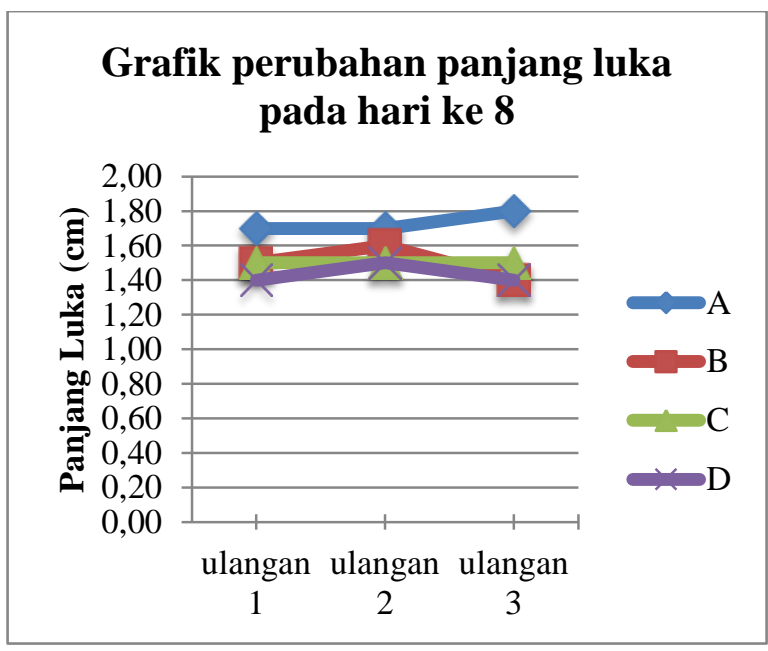

Gambar 1. Perubahan Panjang Luka Pada Hari

\section{Pemeriksaan Organoleptik}

Sediaan gel ekstrak ikan toman (Channa micropeltes) diperoleh hasil yang berbeda pada setiap perlakuan dimana pada perlakuan A $(0 \%)$ dan perlakuan $B(1.5 \%)$ diperoleh warna bening putih, memiliki bau yang Hasil pengujian organoleptik pada formulasi khas seperti gel serta memiliki tekstur yang lembut dan untuk perlakuan $C(3 \%)$ dan perlakuan $D$ $(4.5 \%)$ diperoleh hasil uji organoleptik dengan warna sedikit keruh, memiliki bau yang khas seperti gel pada umumnya dan memiliki tekstur yang lembut.

\section{UJi Daya Sebar}

Hasil pengujian daya sebar di peroleh hasil yang berbeda dari setiap perlakuan rata-rata daya sebar yang diperoleh untuk perlakuan $\mathrm{A}(0 \%) 4,7 \mathrm{~cm}$, pada perlakuan $B(1.5 \%)$ di peroleh daya sebarnya $5.43 \mathrm{~cm}$, perlakuan C (3\%) diperoleh daya sebar 5.46 dan pada perlakuan $\mathrm{D}(4.5 \%)$ diperoleh daya sebar 5.66. daya sebar yang paling tinggi terdapat pada perlakuan $\mathrm{D}(4.5 \%)$.

\section{Hasil Uji Invivo pada Mencit (Mus musculus)}

Pemberian gel ekstrak ikan toman (Channa micropeltes) pada luka mencit (Mus musculus) pada hari ke 4 pengaruh nyata pada perubahan panjang luka bakar mencit (Mus musculus), Hasil perhitungan diperoleh Fhitung > Ftabel maka dilanjutkan dengan uji lanjut BNJ, Berdasarkan hasil uji beda nyata jujur (BNJ) $5 \%$ bahwa pada perlakuan A-B, A-C berbeda nyata $A-D$ sangat berbeda nyata $B-C, B-D, C-D$ tidak berbeda nyata.

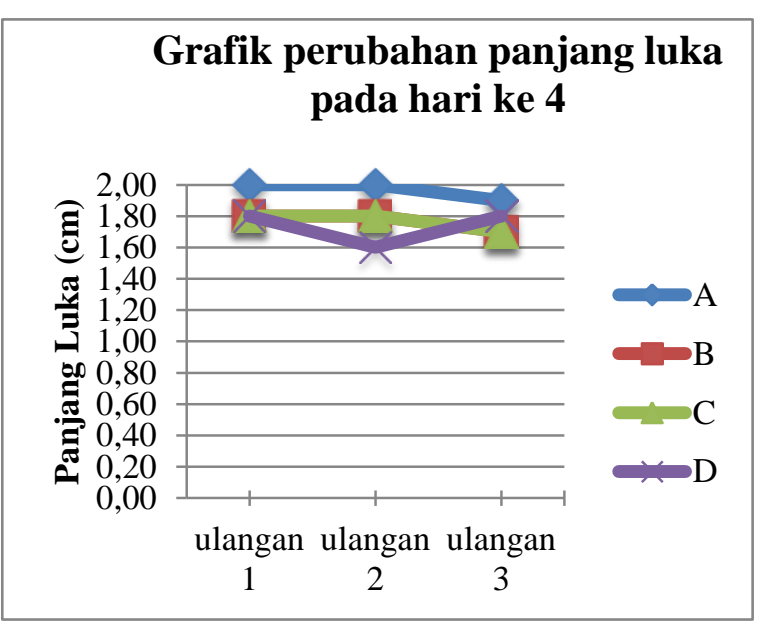

Gambar 2. Perubahan Panjang Luka Pada Hari 
Pemberian gel ekstrak ikan toman (Channa micropeltes) pada luka bakar mencit (Mus musculus) pada hari ke 8 pengaruh sangat nyata terhadap perubahan panjang luka bakar, hasil perhitungan diperoleh $\mathrm{F}$ hitung $>$ Ftabel maka dilanjutkan dengan

\section{Grafik perubahan panjang luka pada hari ke 12}

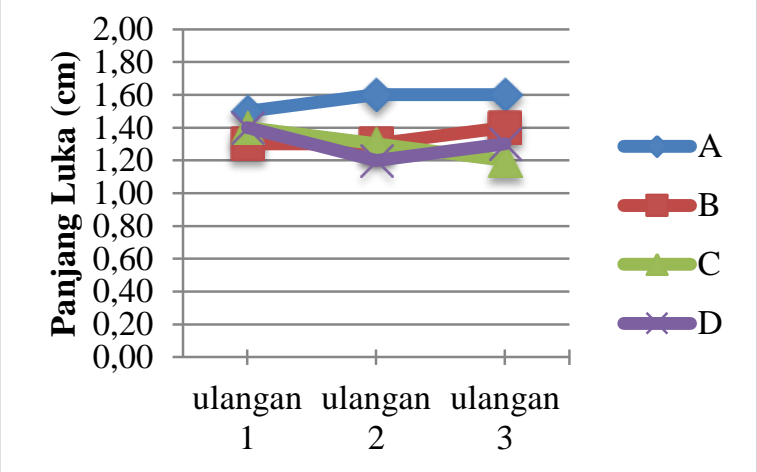

Gambar 3. Perubahan Panjang Luka Pada Hari Ke 12

Pemberian gel ekstrak ikan toman (Channa micropeltes) pada luka bakar mencit (Mus musculus) pada hari ke 12 pengaruh nyata terharap perubahan panjang luka bakar, hasil perhitungan diperoleh $F$ hitung > Ftabel maka dilanjutkan dengan uji lanjut BNJ, Berdasarkan uji beda nyata jujur (BNJ) $5 \%$ sebanyak bahwa pada hari ke 12 perlakuan $A-B, A-C$, $A-D$ sangat berbeda nyata $B-C, B-D$ dan $C-D$ tidak berbeda nyata.

\section{Pembahasan Uji Invivo}

Data hasil pengukuran luka dianalisis statistik menggunakan program Rancangan Acak Lengkap menunjukkan bahwa kemudian analisis data dilanjutkan dengan uji One Way ANOVA.

Penambahan ekstrak ikan toman (Channa micropeltes) dengan konsentrasi yang berbeda dalam sediaan gel tidak mempengaruhi proses penyembuhan luka. Namun, dari semua kelompok perlakauan penambahan ekstrak ikan toman (Channa micropeltes) memiliki persentase penyembuhan luka yang berbeda, hal ini disebabkan oleh beberapa faktor yakni kondisi lebar dan kedalaman luka, kondisi efeksi luka, kondisi metabolik dan umur hewan percobaan. Menurut Purnama et al. (2017), menyatakan bahwa proses penyembuhan luka merupakan suatu proses yang kompleks karena uji lanjut BNJ, Berdasarkan uji beda nyata jujur (BNJ) $5 \%$ sebanyak dan $1 \%$ bahwa pada perlakuan $A-B, A-$ C, A-D sangat berbeda nyata, B-C, B-D dan C-D tidak berbeda nyata. terdapat kegiatan bioseluler dan biokimia yang terjadi secara berkesinambungan. Selain itu proses penyembuhan luka tidak hanya terbatas pada regenerasi yang bersifat lokal tetapi juga di pengaruhi oleh faktor lain, seperti umur, nutrisi, metabolik dan imunologi. Selama tahap penyembuhan luka proses angionesis merupakan faktor yang sangat berperan dalam menyediakan nutrisi dan oksigen pada luka serta meningkatkan pembentukan jaringan granulasi, selain itu pada kelompok perlakuan $A$ (Kontrol negatif) juga mengalami proses penyembuhan luka, artinya tubuh secara alami dapat memulihkan dan mempercepat penyembuhan luka.

Pada hari ke-4 terjadi luka, pembuluh darah pada bagian yang terluka tersebut terputus sehingga terjadi pendarahan. Untuk menghentikan pendarahan, ujung pembuluh darah yang terluka akan mengkerut dan saling lengket satu sama lain sehingga membentuk seperti jala, serta trombosit akan membentuk gumpalan atau bekuan darah sebagai penyumbat untuk berusaha menghentikan pendarahan. Allauddin (2016), menyebutkan bahwa pada saat terjadi luka, kulit akan menunjukkan tandatanda inflamasi yang mana benda asing dari luar tubuh masuk melalui luka yang terbuka, sehingga memicu gangguan tekanan hidrostatik dan menimbulkan perbedaan konsentrasi di dalam dan di 
luar sel melalui jalur osmotik, akibatnya terjadi peradangan pada area luka.

Pada hari ke-8 terjadi peningkatan presentase penyembuhan luka yang signifikan antar kelompok perlakuan hal ini menunjukkan bahwa pada hari ke 8 pemberian sediaan gel ekstrak ikan toman (Channa micropeltes) memberikan pengaruh terhadap penyembuhan luka. Nutrisi yang terkandung dalam segiaan gel ekstrak ikan toman (Channa micropeltes) adalah protein albumin. Fibroblas (menghubungkan sel-sel jaringan) yang berpindah kedaerah luka mulai 24 jam pertama setelah terjadi luka. Diawali dengan mensintesis kolagen dan substansi dasar yang disebut proteoglikan kira-kira 5 hari setelah terjadi luka. Absorsi zat aktif albumin kedalaman luka berperan penting dalam fase proliferasi fase ini merupakan fase dimana terjadi pembentukan jaringan granulasi pada area luka. Selama terjadinya fase proliferasi albumin berperan dalam proses pengembangan jaringan granulasi dan kekuatan kolagen. Selain itu, albumin juga berperan membawa oksigen dalam darah dan nutrisi yang diperlukan dalam pembentukan jaringan sel baru. Irwanda et al. (2014), menyatakan bahwa fase proliferasi albumin mempengaruhi tingkat dan kualitas penyembuhan luka, berperan dalam proses pengembangan jaringan granulasi, proses penyembuhan kolagen dan kekuatan kolagen. Kolagen adalah substansi protein yang menambah tegangan permukaan dari luka. Jumlah kolagen yang meningkat menambah kekuatan permukaan luka sehingga kecil kemungkinan luka terbuka. Kapilarisasi dan epitelisasi tumbuh melintasi luka, meningkatkan aliran darah yang memberikan oksigen dan nutrisi yang diperlukan bagi penyembuhan.

Pada hari ke-12 terjadi proses reorganisasi kolagen yang berperan dalam jaringan sel, meningkatnya kekakuan dan kekuatan pada kulit atau fase maturasi dimulai hari ke-21 dan berakhir 1-2 tahun. Fibroblas terus mensintesis kolagen. Kolagen menyalin dirinya, menyatukan dalam struktur yang lebih kuat. Bekas luka menjadi kecil, kehilangan elastisitas dan meninggalkan garis putih. Dalam fase ini terdapat remodeling luka yang merupakan hasil dari peningkatan jaringan kolagen, pemecahan kolagen yang berlebih dan regresi vaskularitas luka. Terbentuknya kolagen yang baru yang mengubah bentuk luka serta peningkatan kekuatan jaringan. Terbentuk jaringan parut $50-80 \%$ sama kuatnya dengan jaringan sebelumnya. Kemudian terdapat pengurangan secara bertahap pada aktivitas selular dan vaskularisasi jaringan yang mengalami perbaikan (Syamsulhidjayat, 2005).

Nutrisi lain yang kemungkinan terkandung dalam sediaan gel ekstrak ikan toman (Channa micropeltes) yakni omega 3 atau yang dikenal dengan asam lemak tak jenuh dan omega 6 yang dikenal dengan asam arakidonat, dimana nutrisi tersebut berperan dalam pembekuan darah dan memperlancar sirkulasi darah pada area luka dengan memperbesar pembuluh darah atau vasikontriks.

\section{KESIMPULAN DAN SARAN}

\section{Kesimpulan}

Penambahan ekstrak ikan toman (Channa micropeltes) yang diformulasikan kedalam sediaan gel mempunyai $\mathrm{pH}$ rata-rata 8.46 , mempunyai karakteristik warna bening pada formulasi $0 \%$ dan $1.5 \%$ sedangkan pada formulasi $3 \%$ dan $4.5 \%$ sedikit keruh, memiliki tekstur lembut dengan rata-rata daya

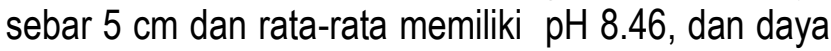
sebar yang diperoleh 5.28 dan penambahan ekstrak ikan toman (Channa micropeltes) yang diformulasikan kedalam sediaan gel efektif dalam penyembuhan luka bakar mencit (Mus musculus) dan perlakuan yang terbaik terdapat pada perlakuan B.

\section{Saran}

Pada penelitian lanjutan dengan penambahan ekstrak ikan toman (Channa micropeltes) sehingga di dapatkan komposisi efektif untuk percepatan penyembuhan luka pada hewan uji.

\section{DAFTAR PUSTAKA}

Hairima, Andrie, Mohammad., dan Fahrurroji, Andhi.2014. Uji Aktivitas Saleb Obat Luka Fase Air Ekstrak Ikan Toman (Channa micropeltes) Pada Tikus Putih Jantan Galur Wistar. Jurnal Mahasiswa Farmasi Fakultas Kedokteran dan IImu Kesehatan UNTAN 1 (1):1-14.

Mulyani, Febriyenti., dan Almahdy A. 2016. Pengaruh Pemberian Esktak Belut (Monopterus albus) pada penyembuhan Luka Bakar Tikus Putih Jantan Sprague-Dawley. Jurnal Sains Farmasi \& Klinis. 2(2); 191-194 
Firlianty, Eddy Suprayitno, Happy Nursyam, Hardok, Annasari Mustafa, 2013. Chemical Composition and Amino Acid Profile of Channidae Collected From Central Kalimantan, Indonesia, International Journal of Science and Technology (IJSTE), Vol 2 No.4, December 2013, 25-29

Hasyim, N., Pare, K. L., Junaid, I., Kurniati, A., 2012. Formulasi dan Uji Efektivitas Gel Luka Bakar Ekstrak Daun Cocor Bebek (Kalanchoe pinnata L.) pada Kelinci (Oryctolagus cuniculus). Majalah Farmasi dan Farmakologi, 16(2), pp.89-94.

Allauddin , Ariq. 2016. Uji Ekstrak Ikan Gabus (Channa striata) Pada Luka Sayat dengan Tikus Putih Jantan Galur Wistar yang Diberikan Secara Oral. Naskah Publikasi. Program Studi Farmasi Fakulta Kedokteran Universitas Tanjugpura. Pontianak

Irwanda, Welly F., Andrie, Mohammad., dan Luliana, Sri. 2014. Uji Efek Penyembuhan Luka Fase Air Ekstrak Ikan Toman (Channa micropeltes) pada Tikus Jantan Wistar yang diberi Luka Sayat. Jurnal Mahasiswa Farmasi Fakultas Kedokteran dan IImu Kesehatan UNTAN 3(1):114.

Syamsulhidjayat R dan Jong W D. 2005. Buku -ajar ilmu bedah. EGC. Jakarta. HIm. 72-101. 